\title{
Grupa zewnętrzna granfalonu jako przykład skazanego na dyskryminację Innego
}

\begin{abstract}
Piotr Łukowski, Grupa zewnętrzna granfalonu, jako przykład skazanego na dyskryminacje Innego [Granfalloon's outgroup - an Another condemned to discrimination]. Interdyscyplinarne Konteksty Pedagogiki Specjalnej, nr 11, Poznań 2015. Pp. 75-91. Adam Mickiewicz University Press. ISSN 2300-391X
\end{abstract}

Granfalloon is a sociopsychological technique of organizating people in a strongly emotionally identified ingroup. A set of various kinds of emblems is the only way successfully defining granfalloon. In means that no idea, no rational motivation nor rational argument is connected with this social phenomenon. That is why granfallooon is strictly related to the minimal group paradigm. The lack of worth results in the seemingly inexplicable power and unusual vitality of the granfallooon. Unfortunately, it makes granfalloon an extremely dangerous phenomenon, especially for members of granfalloon's outgroup. Those people are defined as enemies of the granfalloon. The Third Rich is an example of the particularly pathological granfalloon with precisely defined outgroup of Another, a society of Jews condemned to extermination. The Ron Jones's Third Wave Experience has proved that this technique, also in its really dangerous form, can come into being even in an exclusive school of pupils coming from respectable families living in an old democracy. Undoubtedly, educationalists, teachers and class tutors should possess knowledge about granfalloon as well as the Third Wave Experience.

KEY WORDS: granfalloon, granfaloon's outgroup, psycho-manipulation, The Third Wave experience, Ron Jones, minimal group paradigm 
Na cztery lata przed przeprowadzonym w 1971 r. ważnym stanfordzkim eksperymentem więziennym (Stanford Prison Experiment) przeprowadzonym przez psychologów pod kierunkiem Philipa Zimbardo, w kwietniu 1967 r. w prestiżowym liceum w Palo Alto w Californii doszło do kilkudniowego zdarzenia, które można by nazwać eksperymentem, gdyby nie fakt, iż projekt ten został podjęty przez nauczyciela i uczniów spontanicznie i w taki też sposób był przeprowadzony. Pomysły rodziły się $w$ głowach uczestników $\mathrm{z}$ dnia na dzień, a ich realizacja miała bardzo naturalny, niewymuszany żadnym programem przebieg. Efekt końcowy był zupełnym zaskoczeniem i przeszedł oczekiwania zarówno uczniów, jak i rodziców oraz nauczycieli. Także dziś ten kilkudniowy, nieoczekiwany incydent z Palo Alto zmusza do refleksji. Początkowo „wstydliwie" zapomniany, obecnie coraz częściej jest przypominany. Nie ma niczego zaskakującego $\mathrm{w}$ stwierdzeniu, że środowisko pedagogów winno być zainteresowane nie tylko samym zdarzeniem, ale również jego teoretycznym rozpracowaniem. Mimo całej wiedzy na temat narodzin niemieckiego faszyzmu, łatwość z jaką uczniowie weszli w zaproponowane im niegodziwe przecież role budzi grozę. Zwłaszcza, że cała historia rozgrywała się $\mathrm{w}$ warunkach wręcz wzorcowej amerykańskiej demokracji. Szczególnie zainteresowanymi tym przypadkiem powinny być teoretycy i praktycy pedagogiki specjalnej. Łatwo bowiem rozpoznawalny $\mathrm{w}$ całej historii motyw granfalonu staje się zjawiskiem groźnym wówczas, gdy wykorzystuje grupę zewnętrzną, czyli ludzi uznanych za "niepożądanie" innych. Zwłaszcza w kontekście nieuchronnego - jak tego dowodzi logika języka naturalnego - myślenia stereotypami, osoby mniej sprawne lub niepełnosprawne mogą się stać niemal "naturalnymi" kandydatami na członków grupy zewnętrznej. Emocjonalne, a zwłaszcza przesycone złą wolą wykorzystanie takiej grupy w celu kształtowania dominującego $\mathrm{w}$ społeczeństwie sposobu myślenia bazującego na wykreowanym granfalonie np. „ludzi pełnowartościowych” może prowadzić nie tylko do osobistych tragedii, lecz także do degradacji osobowości głównie członków granfalonu. Choćby z tego powodu refleksja nad granfalonem uświadamiająca istnienie od- 
powiadającej mu grupy zewnętrznej ludzi skazanych na jakąś formę dyskryminacji powinna towarzyszyć opracowywaniu oraz realizacji takich projektów jak chociażby inkluzyjna edukacja osób z niepełnosprawnościami. Trudno też wyobrazić sobie uczciwe i rzetelne rozważania dotyczące kwestii eugenicznych bez odniesienia do zagrożeń jakie stwarza prowadzona na skalę społeczną manipulacja "odpowiednio" zdefiniowanym granfalonem.

\section{Uczniowie z PaloAlto ${ }^{1}$}

Doświadczenie Trzeciej Fali (The Third Wave Experience) rozegrało się na przestrzeni zaledwie pięciu dni, od poniedziałku do piąt$\mathrm{ku}$. Projekt edukacyjny poświęcony autorytaryzmowi miał być realizowany przez cały semestr. Jednak już na samym początku wymknął się spod kontroli, co spowodowało, iż niezależnie od planów Jonesa, przerwania eksperymentu zażądali oburzeni nauczyciele i rodzice. Chociaż początkowo projekt był działaniem ograniczonym do jednej z drugich klas liceum (uczniowie w wieku 15 lat) już pod koniec trzeciego dnia skupiał przeszło dwustu silnie rozemocjonowanych, oddanych sprawie wyznawców ruchu Trzeciej Fali.

Na pomysł projektu Ron Jones, absolwent Harvardu, wówczas 36-letni nauczyciel historii, wpadł po wysłuchaniu serii pytań i komentarzy wypowiedzianych przez uczniów podczas prowadzonej przez siebie lekcji z historii najnowszej. Wyrażali oni swoje szczere oburzenie i zdumienie faktem, iż w XX w., w europejskim kraju,

1 Wiedza na temat incydentu Trzeciej Fali wciąż nie jest dostatecznie upowszechniona. Wykorzystane tu informacje są zaczerpnięte z coraz liczniejszych stron internetowych poświęconych temu zdarzeniu. Wśród nich warto wymienić The third wave, 1967: an account - Ron Jones https://libcom.org/history/the-thirdwave-1967-account-ron-jones [2.04.2016]. Szczególną wartość poznawczą ma także film dokumentalny z 2010 r. Plan lekcji: Historia trzeciej fali (Lesson Plan: The Story of the Third Wave) zrealizowany przez Philipa Neela, ówczesnego ucznia Palo Alto, członka Trzeciej Fali. Prezentacja wspomnień Rona Jonesa, dyrektora szkoły, nauczycieli oraz uczniów jest przepleciona komentarzami Philipa Zimbardo, interpretującego i wyjaśniającego kolejno przypominane fakty. 
jakim przecież są Niemcy, udało się urzeczywistnić tak niewyobrażalne $w$ skutkach i głęboko patologiczne zjawisko jak nazizm. Z nieukrywanym poczuciem wyższości zgodnie twierdzili, że im, wychowanym $w$ demokratycznym państwie nie grozi fascynacja autokracją i że oni nie ulegliby wpływowi żadnej totalitarnej propagandy. W takiej sytuacji Jones uznał, iż najlepszą naukę uczniowie wyniosą z osobistego przeżycia tego, co tak bardzo nie mieściło im się w głowie. Niestety, nie zdawał sobie sprawy ze skutków, jakie wywoła realizacja jego pomysłu. Dzisiaj wiemy, że podobne eksperymenty wymagają odpowiedniego przygotowania zwłaszcza pod względem ewentualnych zagrożeń, jakie mogą dotknąć psychikę ludzi poddanych eksperymentowi. Zamiast tego Jones spontanicznie zaczął realizować swój projekt, z dnia na dzień zastanawiając się, co zrobić nazajutrz, także wdrażając $\mathrm{w}$ życie podobnie spontaniczne pomysły uczniów. Zapłacił za to wysoką cenę utraty praw nauczania. Obecnie prowadzi zajęcia o charakterze terapeutycznym z ludźmi niepełnosprawnymi intelektualnie. Doświadczenie Trzeciej Fali przedstawił w sztuce teatralnej pod tytułem The Wave.

Pierwszy dzień projektu Jones przeznaczył na ustanowienie nowych zasad funkcjonowania klasy. Dotychczas uczniowie mogli zwracać się do niego po imieniu. Jednak z dniem rozpoczęcia projektu taka poufałość została wykluczona. „Panie Jones” stała się jedyną dopuszczalną formą zwracania się ucznia do nauczyciela. Uczniowie musieli też zrezygnować z rozwlekłych wypowiedzi, każdą ograniczając do maksymalnie trzech (!) słów oraz siedzieć w ławkach w "postawie zasadniczej”. Przez całą lekcję pozostawali więc wyprostowani, z rękami założonymi do tyłu, ze złączonymi kolanami i stopami przylegającymi do podłogi. Na drugi dzień, idąc do szkoły Jones przypuszczał, że uczniowie zasiądą w ławkach w tradycyjny, dobrze znany swobodny sposób. Tymczasem ze zdumieniem zobaczył uczniów siedzących dokładnie tak, jak pierwszego dnia. Przestrzeganie tych, wydawać by się mogło, drugorzędnych zasad dotyczących form zachowania wpłynęło znacząco na... myślenie i emocje uczniów. Podobny wpływ na zachowanie miało również przećwiczone pierwszego dnia sprawne zajmowanie miejsc przez wszystkich uczniów wchodzących do klasy. Z se- 
kundnikiem Jones sprawdzał szybkość zajmowania miejsc, kilkakrotnie każąc powtarzać wciąż jego zdaniem zbyt wolne wbieganie do sali lekcyjnej. Gdy wreszcie zajmowanie miejsc zajęło czas zadowalający Jonesa, okazało się, że uczniowie spontanicznie zapragnęli pobić ten rekord, co im się zresztą udało. Tutaj zauważmy jedynie, że poza zerwaniem ze „złą przeszłością” nowe zachowanie uczniów miało ważny pozawerbalny charakter. Bez głoszenia jakiegokolwiek komunikatu, nie przekazując żadnej merytorycznej treści, wpływało na myślenie uczniów w ten sposób, że czyniło ich psychicznie gotowymi do akceptacji nowych, chociaż wciąż nieprzedstawionych im treści. Przypomnijmy, że wyprana z treści postać oddziaływania ma charakter fundamentalny dla procesu manipulacji. Należy dodać, iż cały projekt cechował się brakiem merytoryczności, aż do samego końca.

Drugiego dnia Jones wraz z uczniami nadał klasie nazwę „Trzecia Fala". Wyjaśnić tu należy, iż wybór ten w najmniejszym nawet stopniu nie był przejawem fascynacji Trzecią Rzeszą, nie miał też do niej nawiązywać - przez cały czas trwania projektu uczniowie nawet na chwilę nie zmienili swojego negatywnego stosunku do nazizmu. Nazwą tą uczniowie nawiązali do faktu, iż w czasie przypływu trzecia fala jest tą najsilniejszą z całej serii - sami chcieli stać się właśnie tą najsilniejszą z fal. Podniesiona ręka, której dłoń była zgięta w literę $C$ na kształt grzywy fali stała się nowym gestem pozdrowienia. Co ciekawe, młodzi ludzie chętnie pozdrawiali się tym gestem także poza szkołą, czego wymagał od nich sam Jones, chociaż z oczywistych powodów nie był w stanie tego skutecznie egzekwować. Mimo to wszyscy entuzjastycznie i z prawdziwą dumą zastosowali się do tego polecenia. Ruch Trzeciej Fali zaczął być rozpoznawalny poza murami szkoły. Jones poinformował uczniów, że odtąd są zwartym kolektywem, nie zaś zbiorowiskiem jednostek pozostających w egoistycznych relacjach z otoczeniem. Odwołując się do przykładu sportów zespołowych, wytłumaczył, że siła tkwi we wspólnym dumnym działaniu grupy. Myśl tę wyrażały cztery slogany: „W dyscyplinie siła” (ang. Strength through discipline), "We wspólnocie siła” (ang. Strength through community), "W działaniu siła” (ang. Strength through action), „W dumie siła” (ang. Strength 
through pride), które uczniowie musieli nauczyć się głośno i idealnie równo skandować. Służyło temu wielokrotne, coraz to doskonalsze wspólne rytmiczne wykrzykiwanie tych haseł. Należy tu zauważyć fakt, iż odnotowana wcześniej beztreściowość wspólnoty została zachowana, gdyż wspomniane slogany nie wyrażały żadnych treści poza prawdami o charakterze organizacyjnym. To puste merytorycznie wykreowanie stowarzyszenia stwarzało szansę groźnego $\mathrm{w}$ skutkach wykorzystania grupy $\mathrm{w}$ niemal dowolnym celu wskazanym przez nauczyciela. Tak oto $\mathrm{w}$ ciągu dwóch dni Jones stał się wzorcowym przykładem niezwykle skutecznego manipulatora.

Trzeciego dnia Jones rozdał uczniom małe karteczki, które miały pełnić funkcję legitymacji członkowskich ruchu. Sam też uprzedził, że na trzech karteczkach zaznaczył czerwony krzyżyk oznaczający, że osoby posiadające tę specjalną legitymację zostały mianowane jego informatorami. W rzeczywistości, jak się później okazało, wielu uczniów donosiło Jonesowi na swoich kolegów, jeśli tylko dostrzegli zachowanie niezgodne z przyjętymi w Trzeciej Fali ustaleniami. Zadenuncjowanych przez kolegów „zdrajców” Jones karał publicznie, czyli przed całą klasą. Musieli więc albo przez resztę lekcji stać pod ścianą, albo wyrzucał ich z zajęć, nakazując spędzenie reszty czasu w bibliotece. Poza donosicielami, z grupy wyłonili się spontanicznie "ochroniarze" Jonesa. Od tej pory nauczyciel chodził po szkole $\mathrm{w}$ asyście kilku ochroniarzy, którzy dumnie maszerowali za nim w odległości jednego kroku. Od tego dnia niemal cała szkoła pozdrawiała się gestem Trzeciej Fali w ten sposób, że najpierw gestem pozdrawiano Jonesa, później Jones w ten sam sposób odpowiadał pozdrowieniem, na co uczniowie znów odpowiadali pozdrowieniem, na które tym samym gestem reagowali ochroniarze. Efekt był porażający - gdy Jones szedł korytarzem, przez szkołe przepływała prawdziwa fala pozdrowień przypominających nazistowskie wznoszenie rąk.

W czwartym dniu, naciskany przez otoczenie Jones postanowił zakończyć eksperyment. Przyczyną była dostrzegalna gołym okiem demoralizacja członków ruchu. Uczniowie przestali widzieć cokolwiek złego w donoszeniu na kolegów - w końcu ruch był najważniejszy. Dochodziło do tego, że kolega donosił na swojego najlep- 
szego od lat przyjaciela za wypowiedziany w domu (!) żart na temat Trzeciej Fali. Później przyjaciel ten był karany na oczach całej grupy w tym denuncjatora, który nie przejawiał ani żalu, ani wstydu przed zadenuncjowanym kolegą. Dochodziło też do przemocy psychicznej, a nawet fizycznej. Na korytarzach pojawiły się ławki punkty werbunkowe Trzeciej Fali. Przechodzący uczniowie byli agresywnie nagabywani, aby wstąpić do ruchu. Ważne jest to, że gdy zaczepiani po latach wspominali te zdarzenia, podkreślali, że agitatorzy w żaden sensowny sposób nie potrafili wyjaśnić, jakie są cele ruchu i dlaczego warto do niego przystąpić. Naturalnie fakt ten wynikał z tego, że ruch nie miał programu. Dlatego nagabywani uczniowie słyszeli jedynie powtarzane jak mantra wspomniane wcześniej cztery slogany: „We wspólnocie siła”... Co gorsza, dochodziło też do pobić tych, którzy pozostawali poza ruchem - oni po prostu z definicji stawali się wrogami organizacji. Osobą pobitą był m.in. redaktor gazetki szkolnej, który starał się obiektywnie opisać fenomen Trzeciej Fali. Kilkuset osobowa grupa uczniów stała się groźnym dla otoczenia bezideowym monolitem, posługującym się jedynie chwytliwymi sloganami. Aby zakończyć projekt, Jones ogłosił, że Trzecia Fala ma znacznie szerszy zasięg obejmujący uczniów szkół innych stanów i że ten ogromny skupiający tysiące młodych ludzi ruch należy zjednoczyć, aby przejął władzę, zaczynając od obalenia (!) rządu USA. Jones poinformował, że nazajutrz odbędzie się $\mathrm{w}$ auli wiec, na którym zostanie przedstawiony kandydat na prezydenta USA oraz program nowopowstałej partii.

W piątek w zaciemnionej auli zebrani tłumnie uczniowie długo wpatrywali się w migający śnieg na ekranie niepodłączonego do anteny, ale od samego początku włączonego telewizora. Oczekiwali pojawienia się ich nowego przywódcy. Wyjście zabezpieczali ochroniarze, ale go nie blokowali. Gdy więc atmosfera stała się szczególnie depresyjna, niektórzy uczniowie zaczęli uciekać z auli, nie mogąc znieść rosnącego napięcia. Wówczas z cienia wyszedł na środek podium sam Jones i przypomniał, że projekt był fikcją stworzoną, jako symulacja umożliwiająca doświadczenie rodzenia się systemu totalitarnego. $Z$ ust Jonesa padły wówczas pod adresem uczniów wyjątkowo mocne i gorzkie słowa. Stwierdził on wprost, 
że to, co obserwował każdego z czterech ostatnich dni, napawało go rosnącym obrzydzeniem. $W$ ten bezpardonowy sposób projekt Trzeciej Fali został zamknięty. Uczniowie byli w szoku. Po latach niektórzy z uczniów, wracając pamięcią do tamtego piątku, przypominają, iż twarze koleżanek i kolegów oświetlane jedynie wciąż migającym monitorem były przerażająco puste i podobne do znanych z filmów twarzy zombi. Wielu z nich, wychodząc $\mathrm{z}$ auli, po prostu płakało, inni nie wiedzieli jak się zachować. Wszyscy wyglądali na psychicznie rozbitych. Ich wspaniały ruch, który nadał ich życiu sens (jaki?) okazał się oszustwem i legł w gruzach.

Po latach, w roku 1981 Todd Strasser, amerykański pisarz specjalizujący się $\mathrm{w}$ powieściach adresowanych do dorastającej młodzieży, a traktujących o trudnych życiowych dylematach, napisał książkę The Wave, w której sfabularyzował eksperyment Trzeciej Fali². Lokalizując akcję w 1969 r. oraz zmieniając nazwiska bohaterów, opisał cały incydent dzień po dniu. Książka stała się lekturą obowiązkową w niemieckich, izraelskich, a także w wielu amerykańskich szkołach. Dzisiaj zjawisko Trzeciej Fali służy jako przykład powstawania gangów młodocianych, w których głównym czynnikiem kreującym grupę jest tzw. presja rówieśnicza (ang. peer pressure, także social pressure). Wydaje się jednak, że takie spojrzenie na ten historyczny już fenomen spłyca jego faktyczny sens i zmienia właściwą wymowę zdarzeń i postaw. Znacznie więcej można wynieść z doświadczenia, jakim była Trzecia Fala, analizując ją jako kreowany przez Jonesa granfalon. Wskazuje na to obecna, niemała już wiedza na temat tego właśnie fenomenu.

\section{„Minimalność" i spontaniczność powstawania granfalonu}

Słowo "granfalon" (ang. granfalloon) wprowadził do literatury pieknej Kurt Vonnegut w 1963 r., publikując swoją sławną powieść Kocia kołyska ${ }^{3}$, której jedna z drugoplanowych bohaterek urodzona

2 T. Strasser, The Wave, Dell Publishing Co., New York 1981.

${ }^{3}$ K. Vonnegut, Kocia kotyska, Albatros, Warszawa 2012. 
i żyjąca $w$ Indianie nieustannie tropi pochodzenie sławnych ludzi, sprawdzając, czy także nie urodzili się w tym stanie. To nieustanne rozpoznawanie ludzi służy potwierdzeniu jej tezy, iż ludzie z Indiany są wyjątkowi i wspaniali. Mamy więc przypadek typowego granfalonu. Innymi przykładami tego fenomenu skutecznie dzielącego ludzi na swoich i obcych są zdaniem Vonneguta narody i religie. $\mathrm{Z}$ punktu widzenia obowiązującego $\mathrm{w}$ psychologii znaczenia tego słowa ani naród, ani religia nie spełniają jednak definicji granfalonu, w przeciwieństwie do wspomniane wyżej dzielenie ludzi na pochodzących z Indiany i pozostałych. Granfalon jest bowiem dumnym i bezsensownym stowarzyszeniem ludzi. Definicja ta może zaskakiwać, zwłaszcza gdy konfrontujemy ją z inną, a mianowicie z definicją człowieka pojmowanego jako istota rozumna. Definicja granfalonu wskazuje bowiem, iż terminem tym można nazwać jedynie wolne od sensu stowarzyszenie ludzi, czyli takie, które mimo braku idei, treści spajających swoich członków jest źródłem ich wielkiej dumy. Gdzie więc rozumność człowieka? Z jednej strony mamy bezsens stowarzyszenia, z drugiej zaś silną emocjonalność. Faktycznie, jedynie pusta, bo pozbawiona sensu emocjonalność jest siłą tworzenia i podtrzymywania granfalonu. $Z$ definicji jego kreowanie jest wolne od głoszenia merytorycznych komunikatów. Są one zredukowane do sloganów. Niekiedy osoby pierwszy raz spotykające się $\mathrm{z}$ tym zagadnieniem mają problem $\mathrm{z}$ uwierzeniem, iż takie zjawisko w ogóle jest możliwe. Okazuje się jednak, że nie tylko przypadek $z$ Palo Alto dowodzi, iż podobne intuicje są $w$ tym względzie mylące. W latach 60 . XX w. psychologowie zaczęli zwracać uwagę na pewne dość niezwykłe zjawisko. Otóż osoby uczestniczące $w$ eksperymencie są zazwyczaj dzielone na dwie grupy. Badanym czynnikiem oddziałuje się jedynie na osoby z jednej grupy, pozostali ludzie tworzą tzw. grupę kontrolną. Jak wiadomo, tworzą ją wszyscy ci, których nie poddano wpływowi interesującego badaczy czynnika, dzięki czemu ich zachowanie już po ukończeniu eksperymentu będzie służyło za punkt odniesienia w ocenie zachowań ludzi pierwszej grupy, czyli tych, których poddano wpływowi tegoż czynnika. Z metodologicznego punktu widzenia 
ważne jest, aby członkowie obu grup nie różnili się pod żadnym względem. W konsekwencji chodzi więc o to, aby uniknąć sytuacji, w której w jakiejś grupie dominują np. kobiety, mężczyźni, ludzie w pewnym wieku, wykonujący pewien zawód, itd. Dlatego też zazwyczaj kryterium wyłaniania obu grup ma charakter losowy, co oznacza, że jedyną przyczyną przydzielenia danej osoby do danej grupy jest np. ustalony wcześniej wynik rzutu kostką lub monetą podział ma nie mieć żadnego istotnego sensu. Metoda ta spełnia kryterium minimalności podziału, bo trudno sobie wyobrazić jeszcze większe zmniejszenie (redukcję) sensu podziału. Stąd metodologia ta zyskała nazwę „paradygmatu grupy minimalnej” (ang. minimal group paradigm), zaś każda $\mathrm{z}$ powstałych $\mathrm{w}$ ten sposób grup jest przykładem tzw. grupy minimalnej. To, co było najistotniejsze, a zarazem zaskakujące w kontekście grup minimalnych, wyrażało się w wykreowaniu emocji spajających członków każdej z grup. Ktoś należący do danej grupy cenił, lubił, szanował innych członków swojej społeczności, do ludzi z grupy drugiej miał natomiast stosunek niechętny, a niekiedy nawet wrogi. Dokładniejsze badania nad tym fenomenem prowadził Henri Tajfel, który uzyskane wyniki opublikował w artykule Experiments in Intergroup Discrimination ${ }^{4}$. Wykazał on, iż podstawą dla dyskryminowania członków grupy innej (ang. to discriminate against), a nie tylko odróżniania czy identyfikacji własnej grupy wystarczy minimalne kryterium podziału na grupy, czyli sam fakt ich wykreowania. Później eksperyment ten powtarzał w rozmaitych odmianach nie tylko Tajfel, ale także Robert Cialdnini czy sam Eliot Aronson. Jedną z odmian eksperymentu Tajfela dowodzącą jak bardzo spontanicznie tworzymy granfalon są dwa eksperymenty przeprowadzone przez Johna Fincha i Roberta Cialdiniego. Uczestniczący w nich studenci mieli nauczyć się życiorysu Grigorija Rasputina, w którym został on przedstawiony w złym świetle ${ }^{5}$. W każdym z dwóch przypadków podzielono studentów na dwie grupy, z których jedna była kontrolną. Studenci

${ }^{4}$ H. Tajfel, Experiments in intergroup discrimination, "Scientific American” 1970.

5 E. Aronson, A.R. Pratkanis, Wiek propagandy, PWN, Warszawa 2003, s. 191-192. 
grupy kontrolnej mieli nauczyć się życiorysu Rasputina z właściwą datą jego narodzin, zaś członkowie grupy poddanej wpływowi czynnika grupy minimalnej dostali te same życiorysy $\mathrm{z}$ jedną zaledwie zmianą: datą urodzin Rasputina, z której wynikało, że czytający i Rasputin musieliby obchodzić urodziny tego samego dnia. Okazało się, że referowanie negatywnego życiorysu Rasputina przebiegało $\mathrm{w}$ niezakłócony sposób jedynie $\mathrm{w}$ grupach kontrolnych - tylko ci studenci bez oporów powtarzali to, czego się nauczyli. Zupełnie inaczej odpytywania studentów przebiegały $\mathrm{w}$ grupie poddanej wpływowi wiadomego czynnika. Ludzie, którzy byli przekonani, że Rasputin urodził się tego samego dnia miesiąca co oni, buntowali się przeciwko tendencyjnemu ich zdaniem wyborowi faktów, twierdzili, że życiorys nie jest prawdziwy, jest nieuczciwie przerysowany itd. Ujawnili tym samym swoją silną sympatię do nieznanej im wcześniej historycznej postaci. W świetle zachowania się studentów grupy kontrolnej należało uznać, że sympatia ta powstała jedynie dzięki odpowiednio spreparowanej dacie narodzin.

\section{Cechy granfalonu}

Oba wyżej przypomniane eksperymenty, które oficjalnie miały sprawdzać umiejętność zapamiętywania możliwie największej liczby faktów z życia Rasputina oraz wiele innych dowodzą tezy, która ujawnia groźne oblicze granfalonu. Elliot Aronson i Anthony Pratkanis tak ją formułują: "Atrakcyjni są dla nas ludzie należący do naszego granfalonu, nawet jeśli ci ludzie są niegodziwi i pozbawieni skrupułów"6. W istocie członek granfalonu ma niezwykle prosty sposób oceny elementów świata w którym żyje. Oceny te zależą od dwóch podstawowych etykietek. Jedną jest nazwa społeczności, drugą zaś nazwa grupy zewnętrznej tegoż granfalonu. Aby mieć orientację na temat rzeczywistości, członek granfalonu musi mieć tę

${ }^{6}$ Ibidem, s. 191. 
rzeczywistość starannie poznaczoną tymi etykietami. Ma on zdanie wyrobione wyłącznie na temat tych elementów, które zostały oznaczone przez twórców (przywódców) społeczności. Reguły myślenia są wówczas proste: „swój” jest dobry, mądry, przyzwoity, godny szacunku, lubiany, kulturalny, na poziomie, itd.; "obcy” zaś jest głupi, zły, nieprzyzwoity, ordynarny, poniżej wszelkiego poziomu, itd. Naturalnie, rzeczywistość może być zupełnie przeciwna. To jednak nie ma dla członka granfalonu żadnego znaczenia. Cięższa forma granfalonu jest bowiem techniką oddziałującą na psychikę w najgłębszy sposób, co w konsekwencji prowadzi do kontroli myśli7. To waśnie potrzeba nieustannej kontroli własnych myśli i wypowiadanych przez siebie sądów sprawia, że ludzie z granfalonu tracą orientację w przypadkach nieoznakowanych. Oni naprawdę muszą mieć świat, którego każdy fragment ma etykietkę. Co ważne, użycie słowa „każdy” w tej charakterystyce nie jest przesadą. Etykietki muszą bowiem znaczyć także te fragmenty i aspekty świata, które ktoś spoza tej społeczności w ogóle nie łączyłby ani z granfalonem, ani $z$ jego grupą zewnętrzną. Członek tej grupy czuje się uwięziony w stale oblężonej twierdzy - walczy nawet wtedy, gdy nikt go nie atakuje. Jednak jego prywatny świat jest rzeczywistością nieustającej wojny z ludźmi z grupy zewnętrznej. Aronson i Pratkanis wprost twierdzą, iż grupa zewnętrzna jest po to, aby ludzie z granfalonu wiedzieli kogo mają nienawidzić. Dodają też, że grupa zewnętrzna pojawia się niejako automatycznie towarzysząc procesowi kreowania granfalonu. Twierdzą, że nienawiść do ludzi z grupy zewnętrznej jest jego drugim obliczem ${ }^{8}$. Grupę zewnętrzną tworzą ci, którzy ani nie należą do granfalonu, ani nie sympatyzują z nim. Grupa zewnętrzna to właśnie skazany na dyskryminację Inny. I tu dochodzimy do sedna reprezentowanego w tytule tej pracy. Ponieważ Innym jest każdy członek grupy zewnętrznej, nienawiść do innego jest motorem działania granfalonu jest jego spoiwem i gwarantem trwałości. Gdyby nie istnienie Innego, granfalon

7 T. Witkowski, Psychomanipulacje, Moderator, Taszów 2006, s. 34.

8 E. Aronson, A.R. Pratkanis, op. cit., s. 269. 
straciłby rację bytu - przecież nie mogą być nim wszyscy ludzie, tylko niektórzy z nich. Granfalon dzieli bowiem świat, a nie łączy. Dla członka granfalonu każdy współtowarzysz jest osobą „właściwą" pod każdym względem: właściwie myślącą, właściwie mówiącą, właściwie działającą. Każdy, kto myśli, mówi i działa inaczej, jest wrogiem. Członków granfalonu poznać właśnie po tym, że zasada pluralizmu przekonań jest dla nich zupełnie niezrozumiała. Świat różnorodności myśli jest czymś złym, niewłaściwym. Jest dla nich zagrożeniem. Tylko własna grupa jest gwarantem jedynie słusznego myślenia, mówienia i działania. Poza nią wszystkie te aktywności są niesłuszne. Widać to było dobitnie w Trzeciej Fali. Rację $\mathrm{i}$ to bezwzględną i niepodlegającą krytyce mieli jedynie członkowie granfalonu. Problem w tym, że zarówno w przypadku Trzeciej Fali, jak i w każdej innej groźnej postaci granfalonu komunikacja przywódcy z członkami nie ma charakteru merytorycznego. Przecież Ron Jones nie przedstawił uczniom żadnego programu poza czterema sloganami o treści organizacyjnej. Co więcej, przywódca granfalonu może tym sloganom zaprzeczyć, co jest jawnym dowodem na beztreściowość (bezideowość) granfalonu. Głosząc więc umiłowanie pokoju, można w imię właśnie pokoju rozpętać wojnę światową, głosząc walkę z nienawiścią można zrobić z niej narzędzie i podstawę komunikowania się, głosząc walkę z korupcją można ją tolerować, usprawiedliwiać, a nawet w niej uczestniczyć, głosząc konieczność obniżania podatków można je dowolnie i bezkarnie podnosić. Wszystko to jest możliwe dzięki temu, że komunikacja jest beztreściowa i zredukowana wyłącznie do haseł. Co ciekawe, taka beztreściowa narracja doskonale sprawdza się właśnie w granfalonie. Członek granfalonu i tak wszystko zrozumie, bo... chce zrozumieć9. Brak treści jest więc pożądany, gdyż każdy należący do

${ }^{9} \mathrm{Na}$ ogromne znaczenie jakie ma pragnienie akceptacji treści dla ich faktycznej akceptacji zwraca uwagę Artur Schopenhauer w swojej książeczce Erystyka, czyli sztuka prowadzenia sporów metodę opatrzoną numerem 35 uważa za tak skuteczną, że wszelki inne muszą jej ustąpić. Jest nią zastąpienie oddziaływania na rozum oddziaływaniem na wolę, czyli chcenie. Zatem, zamiast przekonywać do danych poglądów skuteczniej jest przekonać do ich posiadania. 
granfalonu sam wie najlepiej jak sobie wytłumaczyć pojawiające się sprzeczności. Nieustający dysonans poznawczy jest stałym problemem członka granfalonu, z którym musi się jednak uporać sam.

On nie tylko „logicznie” wytłumaczy sobie zaistniałą sprzeczność, ale w to swoje wytłumaczenie głęboko uwierzy tylko dlatego, że bardzo tego pragnie. $W$ tym samookłamywaniu się stosowane jest tzw. odwrócenie wartości. Zjawisko to nie polega na tym, że członek granfalonu zaczyna cenić zło jako zło, a dobro odrzuca dlatego, że jest dobrem. Tak jak zdecydowana większość ludzi także ci z granfalonu chcą wierzyć, że stoją po słusznej stronie, że bronią prawdy, dobra, uczciwości itd. Dbają, a właściwie to walczą, o korzystną dla siebie samoocenę. Mimo iż stoją po stronie głupoty, nieprawości, korupcji pragną widzieć w sobie obrońców mądrości, prawości, uczciwości. W tym celu w swojej świadomości odwracają oceny wartościujące rzeczywistość. Po tym też można poznać nie tylko ludzi granfalonu, ale wszelkie ofiary manipulacji. W konsekwencji dla ludzi z granfalonu człowiek mądry jest głupcem, głupi zaś mędrcem, uczciwy nieuczciwym, a nieuczciwy uczciwym, ordynarny kulturalnym choć „nieco ekscentrycznym”, a kulturalny ordynarnym itd. Jest to ich sposób na podtrzymanie dobrej samooceny $^{10}$. Nietrudno zauważyć, że podstawą dialogu wewnętrznego członka granfalonu jest samookłamywanie się. Cecha ta dotyczy wszelkich ofiar manipulacji, nie tylko ludzi granfalonu11. Poza odwróceniem wartości istnieje jeszcze jedna łatwo dostrzegalna cecha każdej ofiary manipulacji, a więc i członka granfalonu. Jest nią coś, co Philip Zimbardo określa mianem „wyłączania moralności”12. Fenomen ten polega na stosowaniu podwójnych standardów. Ofiara manipulacji nie stosuje tych samych praw wobec "swoich" i wobec „wrogów”. Członkom granfalonu przysługują wszelkie prawa

${ }^{10}$ P. Łukowski, Logika praktyczna z elementami wiedzy o manipulacji, Wolters Kluwer, Warszawa 2012, s. 284.

${ }^{11}$ Ibidem, s. 278-284; także M. Karwat Rewizja obiegowych pojęć manipulacji, [w:] Przestrzenie manipulacji społecznej, red. D. Doliński, M. Gamian-Wilk, PWN, Warszawa 2014, s. 44.

12 P. Zimbardo, Efekt Lucyfera, PWN, Warszawa 2012, s. 39-42. 
i żadne obowiązki - wszystko potrafią uzasadnić i z wszystkiego potrafią się wytłumaczyć. Przeciwnie, ludzie z grupy zewnętrznej, a więc dyskryminowani Inni nie posiadają żadnych praw, za to mają wszelkie możliwe obowiązki. Dlatego jeśli członek granfalonu zachowuje się poniżej krytyki, jego współplemieńcy uważają, iż jest np. oryginalny. Jednocześnie nie wybaczą nawet nieco ostrzejszego stwierdzenia, które bez wątpienia nie przeczy kulturze osobistej, jeśli tylko pada z ust Innego. Użyte wyżej słowo „współplemieńcy” nawiązuje do myślenia plemiennego, które jest przejawem granfalonu. Do tej pory organizacje międzynarodowe nie są wstanie wytępić zjawiska myślenia plemiennego w wielu krajach Afryki. Jeśli policjant ma napisać raport z miejsca przestępstwa czy chociażby wykroczenia, nie postępuje zgodnie z prawdą, lecz z nakazami plemiennymi. Wybiela więc współplemieńca, obciążając winą członka obcego plemienia, w ogóle nie zważając na to, jaki jest stan faktyczny. Dokładnie tak samo myślą ludzie granfalonu, bez względu na to, czy mieszkają w Afryce, w Azji, czy w Europie.

\section{Podsumowanie}

Przeprowadzona wyżej charakterystyka granfalonu nie jest pełna, co nie jest zaskakujące, gdyż wiedza na ten temat jest dość obszerna i wciąż poszerzana. Dla jasności narracji zostały pominięte odniesienia do przykładu Trzeciej Fali. Takie bieżące komentowanie wydaje się zupełnie zbędne, gdyż czytelnik bez najmniejszego trudu rozpozna, w jaki sposób incydent z Palo Alto ilustruje po kolei omawiane własności granfalonu. Co więcej, można przypuszczać, że doświadczony pedagog jest w stanie wskazać własne przykłady ilustrujące ten fenomen. Nie chodzi tu bynajmniej o granfalony stworzone przez doświadczonego pedagoga, ale takie, które potrafi on trafnie rozpoznać.

Kreowanie granfalonu może być celowe i przeprowadzone $\mathrm{z}$ pełną wiedzą na jego temat, może też być tak jak w przypadku Trzeciej Fali - spontaniczne, osiągnięte bez wiedzy o tym fenome- 
nie, a mimo to zaskakująco fachowe i skuteczne. Już z tego chociażby powodu znajomość zjawiska granfalonu oraz innych technik manipulacyjnych powinna być powszechna wśród nauczycieli i wychowawców, w tym zwłaszcza pedagogów specjalnych. Dzięki niej można zarówno $\mathrm{w}$ porę zapobiec ${ }^{13}$ tej niewątpliwie groźnej patologii, a także uniknąć nieświadomego kreowania tego zjawiska. To, że książka The Wave Todda Strassera stała się lekturą szkolną w Niemczech i Izraelu, można wytłumaczyć, odwołując się do historii. W jednym przypadku mamy potrzebę uporania się z kompleksem przez pokazanie, że groźna postać granfalonu nie jest zjawiskiem typowo niemieckim, zaś w drugim możemy domyślać się realnego strachu przed powtórzeniem się tego, co chociaż na pozór wydaje się nierealne, kiedyś stało się jednak faktem. Pomijając te domysły dotyczące prawdziwych motywów, należy z szacunkiem odnieść się do faktu, iż systemy edukacyjne obu państw objęły edukacją ten niezmiernie ważny $\mathrm{z}$ pedagogicznego punktu widzenia temat. Zwłaszcza że wiedza o manipulacji w tym o technice granfalonu może skutecznie zablokować osiągnięcie celu przez ewentualnych manipulatorów. Eliot Aronson wprost twierdzi, że jeśli mamy walczyć z manipulacją, to już na etapie szkolnym. Po pierwsze dzieci i młodzież są bardzo podatne na wszelką w tym i nieuczciwą perswazję, ale jeszcze z dość dużą łatwością potrafią wyjść ze stanu zmanipulowania, co dorosłym przychodzi z ogromnym trudem, o ile w ogóle jest dla nich osiągalne. Po drugie zaś wiedza na ten temat sprawia, że człowiek uodparnia się na wpływ manipulatora ${ }^{14}$. Zdaniem obu autorów, co było też wyraźnie widoczne w incydencie Trzeciej Fali, należy odróżnić przekonanie o własnej odporności na manipulację od faktycznej odporności, która rzeczywiście może

13 Zapis przejmującego ze względu na skutki, udanego choć nieuczciwego wykreowania wroga w warunkach szkolnych zawiera opowiadanie Murakamiego Milczenie [w:] Zniknięcie stonia, Muza SA, Warszawa 2012, s. 331-350. Manipulatorem, który skutecznie zapanował nad myśleniem i emocjami nauczycieli, zamieniając ich w stado działające bezrefleksyjnie za to z całym okrucieństwem okazał się być licealista.

${ }^{14}$ E. Aronson, A.R. Pratkanis, op. cit., s. 286-303. 
zostać osiągnięta dzięki przekazaniu potencjalnej ofierze wiedzy, która samą treścią profilaktycznie zawstydza. A jak wiemy, wstyd jest niezwykle silnym sposobem wywierania wpływu. Jeśli ktoś już wie, że z inteligentnego człowieka można zrobić głupca podporządkowanego manipulatorowi, gotowego ponosić realne straty i ośmieszać się w imię nie wiadomo czego, zdolnego do niemal wszystkiego, czego tylko zażąda manipulator, a ponadto jeśli ten ktoś wie, jak się taki efekt osiąga i jak poniżająca jest psychologiczna charakterystyka ofiary manipulacji, znacznie trudniej będzie mu ulec procesowi manipulacji.

Istnieje też jeszcze jeden bardzo ważny powód, dla którego pedagodzy powinni posiadać wiedzę na temat granfalonu, a także manipulacji. Otóż zawód ten wymaga od człowieka wewnętrznej wolności, zdolności do sprawiedliwych ocen i otwartości na cudze poglądy. Tymczasem myślenie granfalonem, a więc plemienne, sprawia, że człowiek żadnej z tych cech już nie posiada. Fakt ten dyskwalifikuje każdego, kto chciałby wykonywać zaszczytny zawód pedagoga, jak i każdy inny zawód zaufania społecznego, np. sędziego, prokuratora, policjanta czy dziennikarza. Ludzie granfalonu nie są psychologicznie zdolni do uczciwego pełnienia tych odpowiedzialnych funkcji społecznych.

\section{Bibliografia}

Aronson E., Pratkanis A.R., Wiek propagandy, PWN, Warszawa 2003.

Łukowski P., Logika praktyczna z elementami wiedzy o manipulacji, Wolters Kluwer, Warszawa 2012.

Murakami H., Milczenie, [w:] Zniknięcie stonia, Muza SA, Warszawa 2012.

Przestrzenie manipulacji społecznej, red. D. Doliński, M. Gamian-Wilk, PWN, Warszawa 2014.

Schopenhauer A., Erystyka, czyli sztuka prowadzenia sporów, Alma-Press, Warszawa 2012.

Strasser T., The Wave, Dell Publishing Co., New York 1981.

Tajfel H., Experiments in intergroup discrimination, „Scientific American” 1970.

Vonnegut K., Kocia kotyska, Albatros, Warszawa 2012.

Witkowski T., Psychomanipulacje, Moderator, Taszów 2006.

Zimbardo P., Efekt Lucyfera, PWN, Warszawa 2012. 